\title{
MODEL PENDIDIKAN KARAKTER UNTUK ANAK USIA DINI PERSPEKTIF QS. LUQMAN AYAT 12-19
}

\author{
Rizqiyah Ratu Balqis \\ Fakultas Tarbiyah, IAI Al-Falah As-Sunniyyah Kencong \\ rizqiyahratubalqis@gmail.com
}

\begin{abstract}
Basically, the values of education contained in the QS Luqman verses 12-19, are the values of character education, including: monotheism, gratitude, patience, amar ma'ruf nahi mungkar, religious education, and honesty. The wise character (wisdom) is found in Luqman's educational interaction model with his child and between his family. The dominance of this wise nature underpins the interaction of education carried out to his children. The wise attitude of Luqman is directed at the effort to form characters (children) into human beings, that is, having good character and virtuous character

Key Word: Model, Pendidikan Karakter, QS Luqman ayat 12-19
\end{abstract}

\section{PENDAHULUAN}

Pendidikan karakter memiliki makna lebih tinggi dari pada pendidikan moral, karena pendidikan karakter tidak hanya berkaitan denga benar salah, akan tetapi menanamkan sebuah kebiasaan (babit) tentang hal - hal yang baik dalam dalam kehidupan, sehingga anak memiliki kesadaran dan pemahaman yang tinggi serta kepedulian dan komitmen untuk menerapkan kebajikan dalam kehidupan ia sehari-hari. Dalam konteks pemikiran Islam, karakter berkaitan dengan iman dan ikhsan.

Istilah yang sangat popular dan memiliki makna yang dalam "Belajar ketika masih kecil ibarat mengukir di atas batu, sedangkan belajar ketika sudah dewasa seperti mengukir di atas air". Istilah tersebut juga mengandung makna yang sesuai dengan konsep pendidikan anak usia dini yang sangat mementingkan stimulasi sejak dini agar anak dapat belajar banyak untuk mengembangkan potensi dan minat yang dimiliki. Berbeda ketika sudah dewasa, apalagi jika menyinggung terkait karakter dan watak yang sudah menjadi kesatuan dalam kepribadian sehingga untuk merubahnya, akan jauh lebih sulit. Sehingga penanaman pendidikan karakter sejak dini menjadi kunci utama dalam mebentuk karakter positif anak dan menjadi pondasi kepribadian serta karakter yang kuat. Upaya pembentukan karakter sesuai dengan budaya bangsa ini tentu tidak semata dilakukan di sekolah melalui serangkaian kegiatan belajar mengajar, akan tetapi juga dengan pembiasaan (habituasi) dalam kehidupan. Dalam ajaran Islam, akhlak manusia menjadi perhatian utama karena merupakan buah dari keimanan dan ibadah seorang muslim, hal ini dikuatkan dengan fungsi kenabian selain ajaran tauhid juga untuk menyempurnakan akhlak manusia. Ajaran Islam sebagai solusi bagi perbaikan moral masyarakat tidak cukup hanya dengan cara membaca rujukannya saja, melainkan harus Jurnal Auladuna| 42

Vol. ㄱ. №. Q2. Iktober 2019 
dibuktikan dengan adanya kajian dan pemahaman secara mendalam terhadap ajaran agama tersebut, yang kemudian diaplikasikan dalam kehidupan sehari-hari secara bertahap dan berkelanjutan sesuai dengan tumbuh kembang manusia secara umum.

Al-Qur`an sebagai pedoman hidup umat Islam telah mengajarkan dan menggambarkan bagaimana pendidikan karakter harus diajarkan kepada anak sebagai bekal yang utama dan fundamental dalam menjalani kehidupan di dunia. Keluarga adalah pendidik yang pertama dan utama, maka pengetahuan tentang cara mendidik anak adalah hal yang wajib dimiliki, ayah berperan sebagai kepala sekolah yang menentukan arah pendidikan serta menyusun kurikulumnya, mencarikan gurunya, menyusun target-targetnya, sedangkan Ibu sebagai almadrasatul ula berperan sebagai guru utama bagi anak-anaknya yang memiliki tugas memberikan pendidikan sejak anak dalam kandungan, ketika lahir hingga dewasa. ${ }^{1}$

Model - model dalam pembelajaran pun juga bervariasi, termasuk model pendidikan karakter untuk Anak Usia Dini. Oleh karena itu penulis tertarik untuk mengkaji tentang model pendidikan karakter bagi Anak usia Dini yang berdasarkan ajaran Islam yang tertuang dalam Q.S Lukman: 12-19, sehingga ke depan bisa menjadi dasar pengembangan model pembelajaran berkarakter secara praktis dan aplikatif.

\section{REDAKSI DAN TERJEMAH QS. LUQMAN AYAT 12-19}

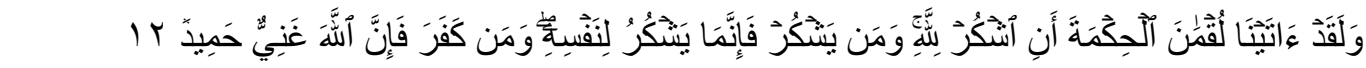
"dan Sesunggubnya telah Kami berikan hikmat kepada Luqman, Yaitu: "Bersyukurlah kepada Allah. Dan Barangsiapa yang bersyukur (kepada Allab), Maka Sesunggubnya ia bersyukur untuk dirinya sendiri; dan Barangsiapa yang tidak bersyukur, Maka Sesunggubnya Allah Maba Kaya lagi Maha Terpuji" (QS. Luqman : 12).

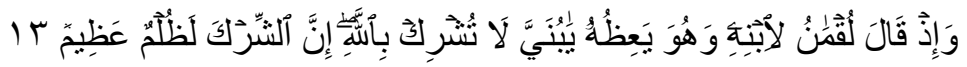
Dan (ingatlab) ketika Luqman berkata kepada anaknya, di waktu ia memberi pelajaran kepadanya: "Hai anakku, janganlah kamu mempersekutukan Allah, sesunggubnya mempersekutukan (Allah) adalah benar-benar kezaliman yang besar"' (QS. Luqman :13).

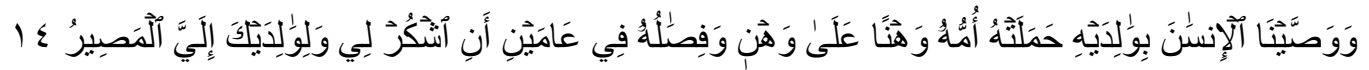

"Dan Kami perintabkan kepada manusia (berbuat baik) kepada kedua orang tuanya; ibunya telah mengandungnya dalam keadaan lemah yang bertambah-tambah dan menyapihnya dalam dua tahun. Bersyukurlah kepada-Ku dan kepada kedua orangtuamu, banya kepada-Ku lah kembalimu." (QS. Luqman :14).

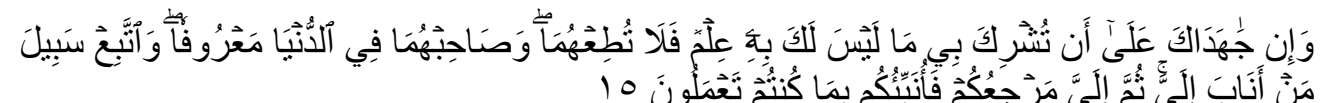

\footnotetext{
${ }^{1}$ Irawati Istadi (2017). Rumahku Tempat Belajarku. Yogyakarta : Pro-U Media 36) Vol. I. No. Q2. Tktober 2019 
"Dan jika keduanya memaksamu untuk mempersekutukan dengan Aku sesuatu yang tidak ada pengetahuanmu tentang itu, maka janganlah kamu mengikuti keduanya, dan pergaulilah keduanya di dunia dengan baik, dan ikutilah jalan orang yang kembali kepada-Ku, kemudian hanya kepada-Kulah kembalimu, maka Kuberitakan kepadamu apa yang telah kamu kerjakan" (QS. Luqman :15).

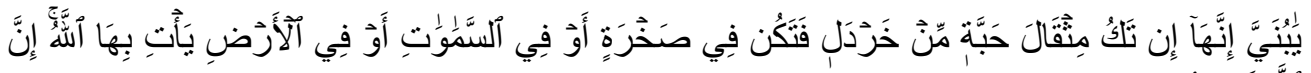

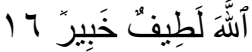

"(Luqman berkata): "Hai anakeku, Sesunggubnya jika ada (sesuatu perbuatan) seberat biji sawi, dan berada dalam batu atau di langit atau di dalam bumi, niscaya Allah akan mendatangkannya (membalasinya). Sesunggubnya Allah Maha Halus lagi Maha mengetahui” (QS. Luqman :16).

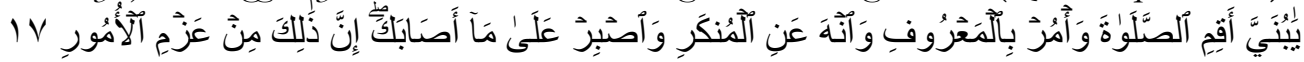

"Hai anakeku, dirikanlah shalat dan surublah (manusia) mengerjakan yang baik dan cegablah (mereka) dari perbuatan yang mungkar dan bersabarlab terhadap apa yang menimpa kamu. Sesungguhnya yang demikian itu Termasuk hal-hal yang diwajibkan (oleh Allah)" (QS. Luqman : 17).

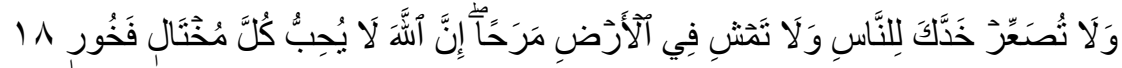
"dan janganlah kamu memalingkan mukamu dari manusia (karena sombong) dan janganlah kamu berjalan di muka bumi dengan angkuh. Sesunggubnya Allah tidak menyukai orang-orang yang sombong lagi membanggakan dirr" (QS. Luqman : 18)

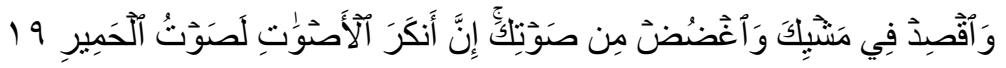

"dan sederhanalah kamu dalam berjalan dan lunakkanlah suaramu. Sesunggubnya seburukburuk suara ialah suara keledai” (QS. Luqman : 19)

\section{TAFSIR KATA-KATA KUNCI QS. LUQMAN : 12-19}

1. Luqman لقمان

Nama seorang yang saleh dan sangat bijak pada masa lalu. Para ulama berbeda pendapat tentang dirinya apakah seorang nabi atau seorang saleh yang sangat bijak. Mayoritas ulama memilih yang kedua. Para ahli tafsir juga berbeda pendapat tentang masa hidupya. Ada yang mengatakan bahwa lukman hidup pada masa nabi Daud. Yang lainnya mengatakan dia adalah anak saudara perempuan Nabi Ayub. Yang lain mengatakan anak bibi Nabi Ayub. Para ulama juga berbeda pekerjaannya. Ada yang mengatakan dia seorang penjahit, tukang kayu, atau penggembala kambing. Namun yang patut dicatat disini adalah bahwa nama Luqman sebagai seorang saleh dan bijak telah dikenal dikalangan orang arab. Luqman sebagai seorang saleh dan bijak yang sangat berharga. Apa yang dikemukakan dalam surah ini adalahhanya sebagian saja. Wasiat luqman pada surah ini mencakup dasarJurnal Auladuna | 44 


\section{Rizqiyah Ratu Bilqis}

dasar agama yaitu akidah, tatakrama bergaul, penyucian diri, dan kegiatan harian Imam alAlusi dalam tafsirnya mengumpulkan sekitar 28 kata-kata hikmah antara lain:

a. Wahai anakku, jauhilah hutang, karena ia akan menjadikan kamu selalu susah diwaktu siang dan malam hari.

b. Janganlah makan makanan kecuali orang-orang yang bertakwa dan bermusyawarahlah dengan ulama.

c. Wahai anakku, dekatilah ulama, desaklah mereka dengan kedua lututmu KarenaAllah akan menyinari hati dengan ilmu pengetahuan sebagaimana Allah menghidupkan bumi yang gersang dengan air terjun.

d. Hendaklah perkataanmu baik, wajahmu selalu cerah, kamu akan dicintai banyak orang melebihi dari satu pemberian yang diberikan kepada mereka.

2. Al-Hikmah الحكمة

Al-Hikmah artinya kebijaksanaan dan kecerdikan, dan banyak perkataan bijak yang berasal dari Luqman, antara lain perkataannya kepada anak lelakinya, "Hai anakku, sesungguhnya dunia itu adalah laut yang dalam, dan sesungguhnya banyak manusia yang tenggelam ke dalamnya. Maka jadikanlah perahumu di dunia bertakwa kepada Allah SWT. Muatannya iman dan layarnya bertawakal kepada Allah. Barangkali saja kamu dapat selamat (tidak tenggelam ke dalamnya) akan tetapi aku yakin kamu dapat selamat.

"Dan perkataan Luqman yang lain ialah, "Barang siapa yang dapat menasehati dirinya sendiri, niscaya ia akan mendapat pemeliharaan dari Allah. Dan barang siapa yang dapat menyadarkan orang-orang lain akan dirinya sendiri, niscaya Allah akan menambah kemuliaan baginya karena hal tersebut. Hina dalam rangka taat kepada Allah lebih baik dari pada membanggakan diri dalam kemaksiatan.Dan perkataannya yang lain, yaitu, "Hai anakku, janganlah kamu bersikap terlalu manis, karena engkau pasti ditelan, dan jangan kamu bersikap terlalu pahit karena engkau pasti akan dimuntahkan.

Dan perkatannya lagi, yaitu, "Hai anakku, jika kamu hendak menjadikan seseorang sebagai teman (saudaramu), maka buatlah dia marah kepadamu sebelum itu, maka apabila ternyata bersikap pemaaf terhadap dirimu dia tidak marah, maka persaudarakanlah ia. Dan apabila ia tidak mau memafkanmu maka hati-hatilah terhadap dirinya. ${ }^{2}$

3. Asy Synkru اشكر

\footnotetext{
${ }^{2}$ Ahmad Mustafa Al-Maraghi, Tafsir Al-Maraghi,Juz XXI, (Semarang: Toha Putra, 1992), hlm. 145-146.

Vol. OI. No. 02. Oktober 2019 Jurnal Auladuna 45
} 
Memuji kepada Allah, menuju kepada perkara yang hak, cinta kebaikan manusia, dan mengarahkan seluruh anggota tubuh serta semua nikmat yang diperoleh kepada ketaatan kepada-Nya.

\section{Ya'izhubun بعظه}

Terambil dari kata (و wa'zh yaitu nasihat menyangkut berbagai kebajikan dengan cara yang menyentuh hati. Ada juga yang mengartikannya sebagai ucapan yang mengandung peringatan dan ancaman. Penyebutan kata ini sesudah kata dia berkata untuk memberi gambaran tentang bagaimana perkataan itu beliau sampaikan, yakni tidak membentak, tetapi penuh dengn kasih sayang sebagaimana dipahami dari panggilan mesranya kepada anak. Kata ini juga mengisyaratkan bahwa nasihat itu dilakukannya dari saat ke saat, sebagaimana dipahami dari bentuk kata kerja masa kini dan datang pada kata (يعظه) ya'iz̧bubu. ${ }^{3}$

5. Inna syirka ladzulmun 'adzim ان الثرك لظلم عظيم

Perbuatan syirik itu merupakan kezaliman yang besar. Syirik dinamakan perbuatan zalim, karena perbuatan syirik itu berarti meletakkan sesuatu bukan pada tempatnya. Dan ia dikatakan dosa besar, karena perbuatan itu berarti menyamakan kedudukan Tuhan, yang hanya dari Dia-lah segala nikmat, yaitu segala nikmat, yaitu Allah SWT dengan sesuatu yang tidak memiliki nikmat apa pun, yaitu berhala-hala.

6. Wawassainal insaana biwaalidaibi ووصينا الانسان بو الديه

Dan kami perintahkan kepada manusia supaya berbakti dan taat kepada kedua orang tuanya, serta memenuhi hak-hak keduanya. Di dalam Al-Qur'an sering sekali disebutkan taat kepada Allah dibarengi dengan bakti kepada kedua orang tuanya. ${ }^{4}$

\section{Jâhadaka جاهدك}

Terambil dari kata جـ “juhd” yakni kemampuan. Patron kata yang digunakan ayat ini menggambarkan adanya upaya sungguh-sungguh. Kalau upaya sungguh-sungguh pun dilarangnya, yang dalam hal ini bisa dalam bentuk ancaman, tentu lebih-lebih lagi bila sekedar imbauan atau peringatan. ${ }^{5}$

8. Al-Misqãla habbah منقالحبة

\footnotetext{
${ }^{3}$ M. Quraish Shihab, Tafsir Al-Misbah,hlm. 298.

${ }^{4}$ Ahmad Mustafa Al-Maraghi, Tafsir Al-Maraghi, Juz XXI, hlm. 153-154.

${ }^{5}$ M. Quraish Shihab, Tafsir Al-Misbah,hlm. 303.

Jurnal Auladuna | 46
} 
Adalah ungkapan untuk segala jenis benda yang berukuran kecil. Artinya, seukuran biji. Bisa juga amal. Maksudnya apa yang setimbang dengan seukuran sebuah biji. ${ }^{6}$

9. Ya bunayya aqimissholah يني اقم الصلوة

Hai anakku dirikanlah sholat, yakni kerjakanlah sholat denga sempurna sesuai dengan cara yang diridhai. Karena di dalam sholat itu terkandung ridha Tuhan, sebab orang yang mengerjakannya berarti menghadap dan tunduk kepada-Nya. Dan di dalam sholat terkandung pula hikmat lainnya, yaitu dapat mencegah orang yang bersangkutan dari perbuatan keji dan mungkar. Maka apabila seseorang menunaikan hal itu dengan sempurna, niscaya bersihlah jiwanya dan berserah diri kepada Tuhannya, baik dalam keadaan suka maupun duka.

10. Wasbir 'ala ma asobaka و اصبر على ما اصابك

Dan bersabarlah terhadap apa yang menimpa kamu dari orang lain. karena kamu membela jalan Allah, yaitu ketika kamu beramar ma'rufatau bernahi munkar kepada mereka. Dia mengetahui bahwa orang yang melakukan amar ma'ruf dan nahi munkar pasti akan mendapatkan gangguan dari manusia, maka dia memerintahkan untuk bersabar. ${ }^{7}$

11. Wala tuso'ir khoddaka ولا تصعر خدك

Janganlah engkau palingkan wajahmu dari manusia, jika engkau berkomunikasi dengan mereka atau mereka berkomunikasi denganmu karena merendahkan mereka atau karena kesombongan. Akan tetapi, merendahlah dan maniskanlah wajahmu terhadap mereka.

12. Wala tamsyi fil ardįi marohaa ولاتمش فى الأرض مرحا

Dan janganlah kamu berjalan dimuka bumi dengan angkuh dan menyombongkan diri, karena sesungguhnya hal itu adalah carajalan orang-orang yang angkara murka dan sombong, yaitu mereka yang gemar melakukan kekejaman dimuka bumi dan suka berbuat zalim terhadap orang lain. akan tetapi berjalanlah dengan sikap sederhana karena sesungguhnya cara jalan yang demikian mencerminkan rasa rendah diri, sehingga pelakunya akan sampai kepada semua kebaikan.

13. Waghdud min sautika واغض من صوتلك

Kurangi tingkat kekerasan suaramu, dan perpendeklah cara bicaramu, janganlah kamu mengangkat suaramu bilamana tidak diperlukan sekali. Karena sesungguhnya sikap yang

\footnotetext{
${ }^{6}$ Syaikh Imam Al-Qurthubi,Tafsir Al-Qurthubi, (Jakarta: Pustaka Azzam, 2009), hlm. 160

${ }^{7}$ Ahmad Mustafa Al-Maraghi, Tafsir Al-Maraghi, hlm. 159.

Vol. I. No. Q2. Tktober 2019

Jurnal Auladuna | 47
} 
demikian itu lebih berwibawa bagi yang melakukannya, dan lebih mudah diterima oleh jiwa pendegarnya serta lebih gampang untuk dimengerti. ${ }^{8}$

\section{MUNASABAH}

Secara harfiah, kata munasabah (مناسبة) berarti perhubungan, pertalian, pertauatan, persesuaian, kecocokan dan kepantasan. Kata al-munasabah adalah sinonim dengan kata almuqarabah (المقاربة) yang artinya mendekatkannya dan menyesuaikannya. Adapun yang dimaksud dengan munasabah dalam terminologi ahli-ahli ilmu Al-Qur'an sesuai dengan pengertian harfiahnya di atas ialah: segi-segi hubungannya atau persesuaian Al-Qur'an antara bagian demi bagian dalam berbagai bentuknya. Yang dimaksud dengan segi hubungan atau persesuaian ialah semua pertalian yang merujuk kepada makna-makna yang mempertalikan satu bagian dengan bagian yang lain. Sedangkan yang dimaksud dengan bagian demi bagian ialah semisal antara kata/kalimat dengan kata/kalimat, antar ayat dengan ayat, antara awal surah dengan akhir surah, antara surah yang satu dengan surah yang lain, dan begitu seterusnya hingga benar-benar tergambar bahwa Al-Qur'an itu merupakan satu kesatuan yang utuh dan menyeluruh (holistik). 'Apabila suatu ayat atau surah sulit ditangkap maknanya secara utuh, maka menurut metode munasabah ini dapat dicari penjelasannya di ayat atau surah lain yang memiliki kesamaan atau kemiripan kenapa harus ke ayat atau surah lain? karena pemahaman ayat secara parsial (pemahaman ayat tanpa melihat ayat lain) sangat mungkin terjadi kekeliruan. ${ }^{10}$

Munasabah surah Luqman mempunyai hubungan atau munasabah dengan surah sebelum atau dengan surah sesudahnya. Dengan surah sebelumnya yaitu dengan Surah Ar-Rum bahwa:

1. Kedua surah sama-sama diawali dengan adanya manusia yang iman dan manusia yang kafir. Bedanya adalah bahwa dalam Surah Ar-Rum yang ditekankan adalah kehancuran orangorang kafir seperti umat-umat terdahulu dan di akhirat masuk neraka, sedangkan orangorang yang beriman dijanjikan kemenangan di dunia dan di akhirat mereka akan masuk surga. Dalam Surah Luqman yang ditekankan adalah keberuntungan yang akan diperoleh

\footnotetext{
${ }^{8}$ Abdullah bin Muhammad bin Abdurrahman Alu Syaikh, Tafsir Ibnu Katsir,Juz 21, (Jakarta: Pustaka Imam Asy-Syafi'I, 2008), hlm. 258.

${ }^{9}$ Muhammad Amin Suma, UlumulQur'an,(Jakarta: RajaGrafindo Persada, 2013), hlm. 236-237

${ }^{10}$ Abu Anwar, Ulumul Qur'an,(Jakarta: Amzah, 2009), hlm. 61

لurnal Auladuna | 48
} 
Rirqiyah Ratu Bilqis

orang-orang yang beriman dan berbuat baik, serta kerugian orang-orang yang kafir di akhirat.

2. Kedua surah juga mengemukakan alam sebagai tanda keberadaan Allah dan kemahakuasaan-Nya. Dalam Surah Ar-Rum yang ditonjolkan adalah kehebatan alam itu sebagai tanda kekuasaan-Nya, sedangkan dalam Surah Luqman yang ditonjolkan adalah kemanfaatan alam tersebut. Keduanya bisa mengantarkan dan mendorong manusia untuk beriman.

3. Kedua surah juga mengetengahkan kesamaan sikap kaum kafir terhadap Al-Qur'an yaitu mereka tidak mempercayainya. Dalam Surah Ar-Rum, mereka mengatakan bahwa AlQur'an adalah sesuatu yang batil atau menyesatkan (mubtil) sehingga mereka menolaknya. Sedangkan dalam Surah Luqman, mereka bersikap membelakangi Al-Qur'an dan tidak mau mendengarnya.

4. Kedua surah juga menyatakan bahwa kiamat pasti, dan janji Allah, baik bagi mereka yang beriman maupun bagi mereka yang kafir, juga pasti. Di akhir Surah Ar-Rum, Nabi SAW diminta tabah menghadapi mereka yang tidak percaya, dan di akhir Surah Luqman, manusia dihimbau agar mempersiapkan menghadapi kiamat itu. ${ }^{11}$

Kemudian munasabah Surah Luqman dengan surah sesudahnya yaitu Surah As-Sajdah adalah:

1. Kedua surah ini sama-sama menerangkan dalil-dalil dan bukti-bukti tentang ke-Esa-an Allah.

2. Dalam Surah Luqman disebutkan keingkaran kaum musyrik terhadap Al-Qur'an, sedang Surah As-Sajdah menegaskan bahwa Al-Qur'an itu sungguh-sungguh diturunkan dari Allah. $^{12}$

\section{GAMBARAN UMUM SURAH LUQMAN}

Surah Luqman adalah surah yang turun sebelum Nabi Muhammad SAW berhijrah ke Madinah. Semua ayat-ayatnya Makkiyah. Demikian pendapat mayoritas ulama. Ada sementara ulama yang mengecualikan tiga ayat yaitu ayat 27, 28, 29, atau dua ayat yakni ayat 27, 28 dengan alasan bahwa ayat-ayat ini turun berdasar diskusi dengan orang-orang Yahudi, yang ketika itu bermukim di Madinah. Pendapat ini, disamping sanadnya lemah, juga kalaupun itu dipahami sebagai diskusi dengan orang Yahudi, maka tidak tertutup kemungkinan untuk dipahaminya terjadi di Makkah, antara kaum muslimin dengan masyarakat Mekkah yang memperoleh

\footnotetext{
${ }^{11}$ Departemen Agama RI, Al-Qur'an dan Tafsirnya, Jil VII, hlm. 532-533.

${ }^{12}$ Departemen Agama RI, Al-Qur'an dan Tafsirnya, Jil VII,hlm.577

Vol. ㅁ․ No. 02. Oktober 2019
}

Jurnal Auladuna | 49 
"Pertanyaan dan contoh keberatan" dari orang-orang Yahudi yang bermukim di Madinah. Ada juga yang hanya mengecualikan ayat 4 atas dasar ayat tersebut berbicara tentang shalat dan zakat. Tetapi, ini pun dinilai lemah. Dapat disimpulkan bahwa surah ini turun sebagai jawaban atas pertanyaan kaum musyrik Mekkah tentang tokoh Luqman yang memang sangat populer di kalangan mereka waktu itu. ${ }^{13}$

Penamaan surah ini dengan surah Luqman sangat wajar karena nama dan nasihat beliau yang sangat menyentuh diuraikan disini dan hanya disebut dalam surah ini. Tema utamanya adalah ajakan kepada tauhid dan kepercayaan akan keniscayaan kiamat serta pelaksanaan prinsip-prinsip dasar agama. Begitu tulis Thabathaba’i dan Sayyid Quthub. Selain itu pula terdapat nilai-nilai karakter dan konsep pendidikan karakter yang dilakukan Luqman terhadap anak-anaknya. Konsep pendidikan yang diterapkan oleh Luqman kepada anaknya mencakup kepada nilai-nilai karakter menurut UNESCO dan IHF (Indonesia Heritage Foundation). Pada dasarnya, jauh sebelum konsep pendidikan karakter atau pendidikan nilai dikaji dan menjadi isu hangat dalam dasawarsa ini, Al-Quran secara tersirat telah menjelaskan tentang konsep pendidikan karakter yang termaktub dalam surat Luqman yang menceritakan tentang model pembelajaran atau pendidikan Luqman yang diterapkan kepada anaknya.

Al-Biqa'i berpendapat bahwa tujuan utama surah ini adalah membuktikan betapa kitab Al-Qur'an mengandung hikmah yang sangat dalam, yang mengantar kepada kesimpulan bahwa yang menurunkannya adalah Dia yang Maha Bijaksana dalam firman-firman dan perbuatanperbuatan-Nya. Allah (tulis al-Biqa'i) telah memulai kitab-Nya dengan menafikan segala keraguan atasnya dan bahwa dia memberi petunjuk untuk orang-orang yang bertakwa (QS. AlBaqarah [2]:2).

Ini dibuktikan-Nya dengan uraian surah-surah sesudahnya. Lalu dimulai lagi dengan surah Yunus -Setelah surah al-bara'ah-dengan menegakkan hikmah kebijaksanaanNya, dan ini pun disusul dengan bukti-buktinya pada surah-surah berikut sampai dengan surah ar-Rum yang lalu. Nah,disini dimulai lagi tahap penjelasan yang baru yang lebih hebat dari sebelumnya. Maka disini kitab suci Al-Qur'an disifati dengan sifat yang melekati sebelumnya yaitu bahwa dia adalah petunjuk dan hidayah untuk al-muhsinin. Al-muhsinin adalah orang-orang yang mencapai puncak, sedang al-muttaqin adalah para pemula. Uraian diatas sejalan dengan nama

\footnotetext{
${ }^{13}$ M. Quraish Shihab, Al-Lubab,(Jakarta: Lentera Hati, 2012), hlm. 167. Jurnal Auladuna | 50
} 
tokoh yang dipilih menjadi nama surah ini yakni Luqman as. Demikianlah lebih kurang pandangan Al-Biqa'i. ${ }^{14}$

\section{ASBAB AL-NUZUL}

Setelah Nabi Muhammad berhijrahke Madinah, sejumlah pendeta Yahudi bertanya kepadanya: "Menurut kabar yang sampai kepada kami, kabarnya engkau pernah mengatakan 'Dan tidaklah kamu diberi ilmu, melainkan hanya sedikit sekali' Apakah yang engkau katakan itu untuk aku atau untuk kamu sendiri?"15. Jawab Nabi: "Yang saya maksudkan adalah untuk kita semua, "kata mereka: "Bukankah engkau mengetahui bahwa kami telah diberi Taurat yang didalamnya terdapat semua penjelasan?” Nabi menjawab: “Apa yang disebut didalam Taurat itu hanyalah sedikit sekali bila dibandingkan dengan ilmu Allah. "Berkenaan dengan hal itu, maka turunlah ayat 28, 29, dan 30 dari surah Luqman ini. Penyebab turunnya surah ini ialah adanya pertanyaan dari orang-orang Quraisy mengenai kisah Luqman dan anaknya, serta mengenai sikap anaknya yang sangat berbakti kepada kedua orang tuanya.

\section{KONSEP PENDIDIKAN KARAKTER DALAM QS. LUQMAN AYAT 12-19}

Adapun pendidikan karakter oleh Luqman yang diajarkan dalam Al-Qur an Surat Luqman ayat 12-19 tersebut meliputi;

1. Pendidikan Tauhid (Ketuhanan/Larangan Mempersekutukan Allah)

Dalam surah Luqman, titik pertama dalam pembentukan keluarga yang harmonis adalah untuk memberikan pendidikan kepada Anaknya sejak usia dini terkait pendidikan tauhid. Karena dengan pendidikan tauhid, maka akan terbentuk dan tertanam pada anak dimasa usia dini karakter keimanan. Keimanan merupakan kenikmatan yang paling besar yang diberikan oleh Allah SWT kepada kita, artinya kita telah diberi petunjuk sehingga menjadi orang yang beriman dan memeluk agama yang benar. Hal itu merupakan kenikmatan yang paling tinggi tiada bandingannya. Mungkin selama ini kita kurang merasakan akan hal itu, dan menganggap bahwa apa yang kita yakini sebagai kebenaran itu merupakan suatu hal yang biasa dan tidak istimewa, padahal dengan keimanan akan menghantarkan seseorang kepada kebahagiaan hidup di dunia ini dan kelak di akhirat.

\footnotetext{
${ }^{14}$ Muhammad Hasbi ash-Shiddiqi, Tafsir Al-Qur'anul Majid An-Nuur, (Semarang: Pustaka Rizki Putra, 2000), hlm. 3197

${ }^{15}$ Muhammad Hasbi ash-Shiddiqi, Tafsir Al-Qur'anul Majid An-Nuur, (Semarang: Pustaka Rizki Putra, 2000), hlm. 3197.

Vol. ㄴ. No. Q2. Dktober 2019

Jurnal Auladuna| 51
} 
Karena apabila keimanan telah tertanam dan terpupuk dengan subur dalam diri seorang mukmin, maka keimanan itu akan terasa indah baginya. Jiwanya menjadi tentram karena hati tertambat kepada Allah SWT. Sebagaimana firman Allah dalam QS Ar Rad ayat 27 - 29

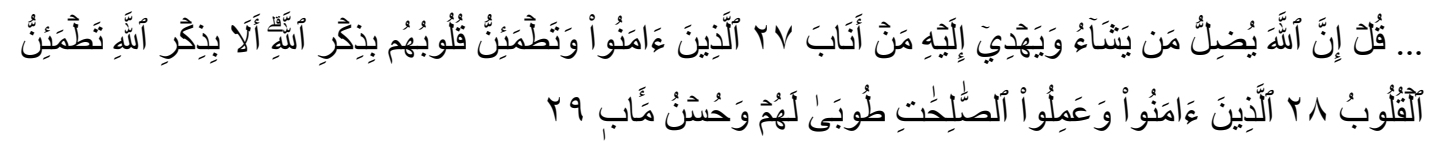

Artinya : "katakanlah, sesungguhnya Allah menyesatkan siapa yang Dia kehendaki dan memberikan petunjuk orang-orang yang bertaubat kepada-Nya, (yaitu) orang - orang yang beriman, dan hati mereka menjadi tentram dengan mengingat Allah. Ingatlah hanya dengan mengingat Allah-lah bati akan menjadi tentram. Orang orang yang beriman dan beramal shaleh, bagi mereka kebahagiaan dan tempat kembali yang baik"”

Dari sini sudah jelas bahwa Al-Quran memberikan teori dalam pembentukan karakter anak yaitu karakter religius yang masuk dalam ranah ke-tauhid-an. Sehingga sejak dini pendidik terutama orang tua harus membentuk dan menanamkan karakter religius ini kepada anak. Anak usia dini memiliki potensi yang sangat luar biasa. Saat itu fikiran serta otaknya masih kosong. Diibaratkan seperti gelas kosong yang belum terisi apapun. sehingga siap untuk diisi air apapun oleh pemiliknya. Begitu pula pada anak usia dini mereka siap diisi berbagai informasi serta pengalaman-pengalaman yang baik. Masa tersebut merupakan fase yang paling subur serta paling dominan bagi seorang pendidik khususnya keluarga untuk menanamkan aturan-aturan atau norma-norma yang baik dan bimbingan serta arahan yang bersih kedalam jiwa anak usia dini.

2. Birrul Walidain (Berbakti Kepada Kedua Orang Tua)

Dalam hal ini Luqman memerintah dan mengajarkan untuk berbakti dan bersyukur kepada ibu dan bapak, mengenai perjuangan ibu ketika mengandung dan memelihara menyusui anak, serta segala bentuk perjuangan dan pengorbanan kepada anaknya yang secara tulus dan ikhlas. Ketaatan seorang hamba kepada Allah adalah ketaatan mutlak, tanpa pengecualian. Sementara ketaatan kepada kedua orang tua dengan pengecualian, selama keduanya tidak meminta untuk mempersekutukan Allah. Dan tetap memuliakan serta melakukan hubungan baik terhadap keduanya.

Konsep pendidikan birrul walidain ini juga tidak lepas dari pendidikan tauhid kepada anak, pada pendidikan tauhid seseorang harus yakin bahwa yang memberikan kenikmatan ketentraman, kebahagiaan hidup di dunia maupun di akhirat serta kesakitan adalah Allah SWT, sehingga pendidikan birrul walidain disini adalah sebagai jembatan dan jalan Jurnal Auladuna | 52 


\section{Rizqiyah Ratu Bilqis}

seseorang terutama seorang anak untuk mendapatkan ridlo dari Allah SWT dalam mencapai kebahagiaan dan ketentraman hidup di dunia maupun di akhirat kelak. Sebagaimana dalam dalam sabda Nabi Muhammad SAW :

$$
\text { رضي الهه فى رضى الو الدين وسخطه في سخط الو الدين }
$$

"Ridlo Allah terkait erat dengan ridlo orang tua dan murka Allah juga terkait erat dengan murka orang tua"

Seorang anak harus tunduk dan patuh kepada orang tua dan memenuhi segala keinginan keduanya, karena yang demikian itu adalah untuk memenuhi perintah Allah dan agar mendapat ridlo Allah SWT. Tetapi jika orang tua menyuruh anak untuk berbuat maksiat, maka sang anak berhak untuk tidak patuh kepada keduanya, karena seseorang tidak boleh mentaati perintah makhluq demi menentang perintah Khaliq.

Dari keterangan di atas, tersirat betapa pentingnya menanamkan karakter kepatuhan anak terhadap orang tua. Sebagai sebuah kritik, pembentukan karakter kepatuhan anak kepada orang tua disini bukan semata mata untuk kebutuhan orang tua yang ingin dihormati, disegani, disanjung ataupun ditakuti oleh anak untuk kepentingan kepuasan, lebih dari itu pendidikan pembentukan karakter tersebut adalah merupakan sebagai bentuk tanggungjawab orang tua kepada anak agar anak selamat dari siksaan Allah SWT.

3. Bersyukur

Dari kisah Luqman yang tertera di dalam QS Luqman ayat 12 telah memberikan teori bagaimana seorang anak terbentuk karakter untuk mengetahui dan merasakan nikmat nikmat yang telah diterimanya dari Allah SWT yaitu yang disebut dengan bersyukur.

Bersyukur kepada Allah SWT bagi orang yang beriman adalah sebuah keharusan. Karena setiap saat, setiap menit, setiap detik kita selalu mengkonsumsi dan menikmati fasilitas serta anugrah Allah SWT. Dalam firman Allah SWT;

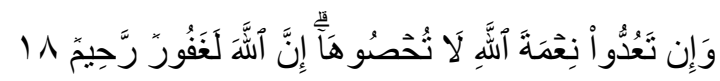

Artinya: "dan jika kamu mengitung hitung nikmat Allah, niscaya kamu tidak akan dapat menentukan jumlahnya” (QS. An Nahl :18)

Dari ayat tersebut telah kita yakini dan rasakan bahwa nikmat Allah SWT yang telah diberikan kepada kita sangatlah nyata dan abstrak, mulai sejak lahir ke dunia hingga sampai saat ini tidak bisa dihitung seberapa banyaknya. Ungkapan tersebut memposisikan kita sebagai makhluq yang dho if sekaligus merupakan pengakuan dan kesadaran sebagai manusia yang harus mengabdi dan beribadah hanya kepada Allah SWT. Pengabdian dan Vol. ㅁ․ No. 02. Oktober 2019 
penghambaan kepada Allah harus dilaksanakan dengan ikhlas hanya semata-mata mengharap ridla dari Allah SWT. Maka dari sinilah perasaan syukur itu tumbuh secara mendalam, yang selanjutnya merefleksi pada tingkat kematangan ritual dan prilaku sosial.

Sejak dini pun, orang tua senantiasa memberikan penanaman pendidikan karakter yang dalam hal ini adalah bersyukur, karena dengan mensyukuri nikmat Allah yang telah diberikan akan memperkuat ke-tauhid-an seorang anak, akan menambah keyakinan bahwa tiada lain yang bisa memberi kebahagiaan didunia dan diakhirat selain Allah SWT. Selain itu, karakter untuk senantiasa bersyukur juga bisa meningkatkan rasa kepatuhan anak terhadap kedua orang tua "birrul walidain" karena dari kasih sayang orang tualah dia bisa merasakan nikmat untuk hidup dengan layak di dunia dan bisa melihat tanda tanda kekuasaan Allah SWT.

4. Kejujuran

Nasehat Luqman mengenai pendidikan kejujuran tidak hanya untuk anak tetapi juga untuk orang tua. Sebesar dan sekecil apapun hal yang kita perbuat dan yang kita sembunyikan, baik dan buruknya diketahui oleh Allah dan akan diganjar dengan balasan yang setimpal. Setelah menyerukan ajaran untuk senantiasa bersikap jujur dalam segala hal dan tindakan, Islam mengecam sikap bohong. Kebohongan merupakan sifat yang hina yang memiliki banyak mudharat dan akibat negatif bagi kehidupan masyarakat. Sayyidah Aisyah Ra berkata, "Tidak ada akhlak yang paling dibenci Rasulullah Saw, melibihi kebencian beliau terhadap sikap bohong"(HR. Tirmidzi).

Kejujuran merupakan tanda-tanda keimanan dan kesucian jiwa serta pertanda dari keselamatan. Karakter jujur menunjukkan keindahan sifat dan ketinggian moral seseorang. Karakter jujur pula lah yang membentuk pelakunya menjadi cinta kepada Allah dan cinta kepada hamba hamba Nya yang beriman. Menanamkan pendidikan karakter jujur kepada anak sejak dini merupakan sebuah kunci bagi kesuksesan anak menuju jalan kebaikan yang diridlai oleh Allah SWT.

5. Pendidikan Ibadah

Setalah Luqman memerintahkan anaknya mengesakan Allah,yang juga mengandung larangan berbuat syirik dan mengingatkan akan kesempurnaan ilmu dan kekuasaan Allah, 
dimana tiada sesuatu pun di dunia ini yang tersembunyi bagi-Nya, kemudian Luqman memerintahkan anaknya agar mendirikan shalat sebagai ibadah yang paling sempurna. ${ }^{16}$

Pendidikan ibadah disini merupakan bentuk ketaatan seorang hamba kepada Tuhannya. Kegiatan ibadah yang sempurna yang dilakukan seorang hamba kepada Tuhannya merupakan bentuk aplikasi sebuah keimanan dan sebagai bentuk rasa syukur seseorang terhadap nikmat nikmat yang telah diberikan Allah SWT kepada hambanya. Allah menyebutkan bahwa diantara sifat hamba-hamba yang beriman adalah mereka yang selalu menyemppatkan diri untuk bersujud dan berdiri dalam shalatnya di malam hari. Sebagaimana dalam surah Al Furqan ayat 63-64:

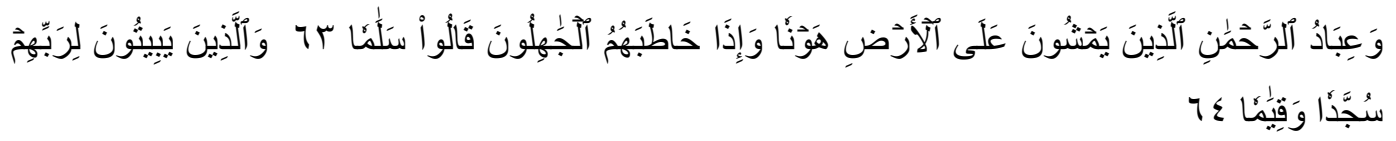

"dan hamba - hamba Tuhan Yang Maha penyayang itu (ialab) orang orangyang berjalan diatas bumi dengan rendah hati dan apabila orang - orang jabil menyapa mereka, mereka mengucapkan kata-kata yang baik. Dan orang yang melalui malam hari dengan bersujud dan berdiri untuk Tuban mereka."

6. Amar Ma'ruf Nahi Mungkar (dakwah)

Dalam hal ini Luqman memberi ajaran kepada anaknya, berupa hikmah bukan dengan kekerasan, yakni dengan cara ajakan atau berupa dakwah dengan mau'idzah hasanah (melalui cara yang dapat menaklukan hati) dan mujadalah yang dapat mencerahkan akal. Sedangkan, cara nahi munkar seperti yang ditetapkan Rasulullah dalam hadist yang diriwayatkan oleh Abu Sa'id, ia berkata "Barang siapa di antara kalian melihat kemunkaran, hendaklah ia mengubahnya dengan tangannya, jika tidak mampu maka dengan lisannya, jika tidak mampu maka dengan hatinya, dan itu adalah selemah-lemah iman" 17

Sehingga pendidikan terhadap anak usia dini itu perlu dilakukan dengan pendekatan dakwah diantaranya dengan "mau'idhah hasanah", memberikan nasihat dengan bahasa yang halus sehingga bisa memberikan pencerahan hati dan fikirannya. Dengan demikian, anak tersebut bisa mudah menerima dan memahami suatu ajaran yang baik dan menolak suatu ajaran yang tidak baik yang bertentangan dengan Qur`an dan Hadist.

7. Sabar

${ }^{16}$ (Al-Ghamidi, Cara MengajarAnak/Murid ala Luqman al-Hakim. Yogyakarta: Sabil, 2011), 211

${ }^{17}$ (Al-Ghamidi, Cara MengajarAnak/Murid ala Luqman al-Hakim. Yogyakarta: Sabil, 2011), 216 Vol. ㅁ. No. Q2. Tktober 2019 
Luqman menasehati dan memerintah anaknya untuk bersabar terhadap apa yang menimpanya, karena sesungguhnya yang demikian itu termasuk hal-hal yang diwajibkan oleh Allah. Dalam hal ini, manusia hendaknya bersabar terhadap cobaan dan rasa berat dalam melaksanakan apa yang diperintahkan, khususnya dalam mendirikan shalat dan berbuat amar ma'ruf nahi munkar. ${ }^{18}$

Menanamkan pendidikan karakter sabar, juga harus dilakukan dan dimulai pada saat anak usia dini. Karena dengan karakter kesabaran itu, dapat memberikan ketahanan anak untuk semangat menjalankan ibadah dalam kondisi apapun. Karakter sabar sangat dibutuhkan setiap anak dalam masa perkembangannya, jika pada masa perkembangan anak tidak ditanamkan karakter dan jiwa kesabaran maka anak akan mudah putus asa yang pada akhirnya anak tersebut akan mendapatkan kegagalan dalam hidup sehingga ia senantiasa akan merasakan kesusahan secara terus menerus akibat ia tidak memiliki ketahanan mental yakni kesabaran.

8. Pendidikan Akhlaq

Dalam hal ini, Luqman mengajarkan kepada anaknya untuk tidak sombong, angkuh, membanggakan diri, takabbur dan merendahkan hamba Allah lain, serta larangan bahagia yang sangat berlebihan. Luqman juga mengajarkan pendidikan akhlak tentang untuk hidup sederhana, ramah, tidak kikir, lurus dan istiqomah dalam menjalan hidup sesuai syariat yang benar, serta peringatan dan nasehat untuk dapat mengendalikan keseimbangan emosional dan rasional. Seperti larangan untuk meninggikan suara.

Dari penjelasan penerapan pendidikan karakter dalam Al-Qur'an Surat Luqman ayat 12-19 menurut kitab tafsir Al-Misbah, maka dapat dapat dikaitkan dengan nilai-nilai pendidikan karakter yang disusun Diknas mulai tahun 2011 yang mana seluruh tingkat pendidikan di Indonesia harus menyisipkan pendidikan berkarakter dalam proses pendidikan, adapun 18 nilai tersebut adalah sebagai berikut:

1) Religius

Sikap dan prilaku yang penuh dalam melaksanakan ajaran agama yang dianutnya, toleran terhadap pelaksanaan ibadah agama lain, dan hidup rukun dengan pemeluk agama lain

2) Jujur

Prilaku yang didasarkan pada upaya menjadikan dirinya sebagai orang yang selalu dapat dipercaya dalam perkataan, tindakan, dan pekerjaan

3) Toleransi

${ }^{18}$ (Al-Ghamidi, Cara MengajarAnak/Murid ala Luqman al-Hakim. Yogyakarta: Sabil, 2011), 249 Jurnal Auladuna | 56 
Sikap dan tindakan yang menghargai perbedaan agama, suku, etnis, pendapat, sikap, dan tindakan orang lain yang berbeda dari dirinya.

4) Disiplin Tindakan yang menunjukkan prilaku tertib dan patuh pada berbagai ketentuan dan peraturan

5) Kerja keras

Tindakan yang menunjukkan prilaku tertib dan patuh pada berbagai ketentuan dan peraturan

6) Kreatif

Berfikir dan melakukan sesuatu untuk menghasilkan cara atau hasil baru dari sesuatu yang telah dimiliki

7) Mandiri

Sikap dan prilaku yang tidak mudah tergantung pada orang lain dalam menyelesaikan tugas-tugas

8) Demokrasi

Cara berfikir, bersikap, dan bertindak yang menilai sama hak dan kewajiban dirinya dan orang lain

9) Rasa ingin tahu

Sikap dan tindakan yang selalu berupaya untuk mengetahui lebih mendalam dan meluas dari sesuatu yang dipelajarinya, dilihat dan didengar

10) Semangat kebangsaan

Cara berfikir, bertindak, dan berwawasan yang menempatkan kepentingan bangsa dan negara diatas kepentingan diri diri dan kelompok

11) Cinta tanah air

Cara berfikir, bertindak, berwawasan yang menempatkan kepentingan bangsa dan negara diatas kepentingan diri dankelompoknya

12) Menghargai prestasi

Sikap dan tindakan yang mendorong dirinya untuk menghasilkan sesuatu yang berguna bagi masyarakat dan mengakui serta menghormati keberhasilan orang lain

13) Bersahabat / komunikatif

Sikap dan tindakan yang mendorong dirinya untuk menghasilkan sesuatu yang berguna bagi masyarakat dan mengakui serta menghormati keberhasilan orang lain

14) Cinta Damai

Sikap dan tindakanyang mendorong dirinya untuk menghasilkan sesuatu yang berguna bagi masyarakat, dan mengakui, serta menghormati keberhasilan orang lain.

15) Gemar membaca

Kebiasaan menyediakan waktu untuk membaca berbagai bacaan yang memberikan kebajikan bagi dirinya

16) Peduli lingkungan

Sikap dan tindakan yang selalu berupaya mencegah kerusakan pada lingkungan alam dan sekitarnya, dan mengembangkan upaya-upaya untuk memperbaiki kerusakan alam yang telah terjadi

17) Peduli sosial

Sikap dan tindakan yang ingin selalu memberi bantuan pada orang lain dan masyarakat yang membutuhkan

18) Tanggung jawab

Vol. DI. №. [2. Zktober 2019 
Sikap dan prilaku seseorang untuk melaksanakan tugas dan kewajiban yang seharusnya dia lakukan terhadap dirinya sendiri, masyarakat, lingkunghan (alam, sosial, dan budaya), negara dan Tuhan Yang Maha Esa. ${ }^{19}$

\section{ANAK USIA DINI DAN PENDIDIKAN KARAKTER}

Pencanangan pendidikan karakter oleh Kemendiknas membawa harapan besar tentang perubahan paradigma pendidikan yang konstruktif dan substantif. Konstruktif karena membentuk manusia berkarakter diperlukan manusia-manusia yang kreatif dan kritis dan akan menjadi trend setter bagi lingkungan. Proses pembentukan manusia berkarakter bukan suatu proses yang singkat tetapi membutuhkan waktu, strategi, finansial dan system terpadu yang dapat mensuport pendidikan karakter menjadi sebuah school culture dan family culture. Tahapan pendidikan dan penanaman karakter setidaknya melalui empat tahapan : Knowing (mengetahui) pada tahapan ini anak diberi pengetahuan tentang baik dan buruknya perilaku dan norma yang ada dalam masyarakat. Tahapan kedua yaitu reasoning yaitu memberikan pemahaman tentang anak yang menimbulkan kesadaran dan dapat merasakan oleh karena itu pada tahapan ketiga disebut dengan feeling, yaitu merasakan dampak ketika anak melakukan kabaikan baik di sekolah maupun dirumah. Tahap yang terakhir yaitu acting dimana anak mengambil tindakan sebagai wujud dari pengetahuan, pemahaman dan perasaan anak sehingga akan terinternalisasi dalam kepribadian anak. Proses internalisasi pendidikan karakter tidak dapat dilakukan jika tidak melibatkan orang tua yang memiliki kontribusi besar dalam tumbuh kembang anak terutama pada tahapan anak usia dini. Pendidikan anak usia dini merupakan salah satu program strategis yang sedang banyak dikembangkan Wortham menyatakan Assesment should involve the child and Family (2005 :22). Artinya identifikasi kebutuhan pendidikan anak usia dini harus melibatkan orang tua dan pengasuh sebagai sumber informasi karena anak-anak banyak menghabiskan waktu dirumah. Sekolah juga berfungsi sebagai sarana komunikasi antara orang tua dan lembaga PAUD untuk kemudian setelah anak mendapatkan pendidikan karakter dapat dikembangkan dan diimplementasikan dirumah.

\section{MODEL PENDIDIKAN KARAKTER PADA ANAK USIA DINI DALAM QS. LUQMAN}

\footnotetext{
${ }^{19}$ Kementerian Pendidikan Nasional, Pengembangan Pendidikan budaya dan Karakter Bangsa, (Jakarta: Badan Penelitian dan Pengembangan Pusat Kurikulum, 2010), 9-10 Jurnal Auladuna | 58
} 
Konsep pendidikan karakter Lukmanul hakim menarik untuk dikaji karena beliau bukanlah nabi dan rasul, beliau merupakan bagian dari masyarakat biasa secara strata sosial maupun ekonomi, dan ulasan konsep ajarannya dalam Al-Qur`an lebih terperinci, terstrukur, dan sistematis, mulai dari ayat ke-12 sampai ayat ke-19. Kemudian, dari konsep pendidikan karakter dalam kisah Luqman yang telah menjadi firman Allah SWT yakni QS. Luqman, maka penulis dapat mengambil beberapa inti model model pembelajaran yang diterapkan Luqman terhadap anaknya.

Model pendidikan karakter yang terdapat dalam surah Luqman ayat 12-19 erat kaitannya dengan pendidikan karakter dalam keluarga. Terutama pendidikan yang diberikan kedua orang tua terhadap anaknya mulai sejak lahir hingga dewasa. Rumah adalah tempat belajar pertama bagi anak-anak. Sementara ibu adalah guru pertama dan guru terbaik. Di tempat tersebut, anak akan belajar apapun dari personil yang ada di rumah, entah itu ayah, ibu, kakek, nenek, kakak, adik dan para tetangganya. Pendidikan anak dalam keluarga untuk mengajarkan kasih sayang, pengertian, komunikasi, rasa percaya diri, dan lain sebagainya harus diajarkan oleh orang tua melalui contoh perilaku kehidupannya. Baik dan buruk perilaku anak merupakan hasil contoh dan didikan dari orang tuanya. Otak anak ibarat spon yang memiliki daya serap yang tinggi. Dia bisa menyerap semua informasi yang didapatkan melalui apa yang dia lihat, dia dengar, dan dia rasakan saat di rumah. ${ }^{20}$

Masalah degradasi moral dalam keluarga perlu segera mendapat penanganan khusus. Hal ini berhubungan dengan masalah kesiapan kita dalam menyongsong era globalisasi. Salah satu upaya penanganan khusus tersebut melalui pendidikan budi pekerti. Karena pendidikan budi pekerti merupakan pendidikan nilai, pihak pertama yang paling cocok memberikan budi pekerti adalah keluaga. ${ }^{21}$

Terkait dengan surah Luqman ada beberapa model yang bisa digunakan untuk menanamkan pendidikan karakter kepada anak usia dini, diantaranya :

1. Model Interaksi dalam Keluarga

a. Model interaksi antar orang tua

Interaksi dan komunikasi ibu dan ayah itu bisa menjadi tolak ukur sebuah keluarga sejahtera atau tidak, disisi lain dalam kepribadian ayah dan ibu masing masing memiliki

\footnotetext{
${ }^{20}$ Damayanti, Panduan Implementasi Pendidikan Karakter di Sekolah. (Yogyakarta : Araska, 2014), 167

${ }^{21}$ Muslich, Pendidikan Karakter: Menjawab Tantangan Krisis Multidimensional. (Jakarta: PT Bumi Aksara. 2011), 92
}

Vol. 미. №. [2. Oktober 2019 
unsur keteladanan, sehingga secara tidak langsung akan mempengaruhi proses terbentuknya sebuah karakter pada anak tersebut. Dengan demikian, interaksi antara ayah dan ibu harus betul betul menunjukkan sebuah keluarga yang sakinah. Komunikasi yang dibangun adalah dengan model proposional, artinya seorang harus mengerti tugas dan kewajiban ayah, dan seorang ibu harus mengerti tugas dan kewajiban ibu. Baik buruknya hubungan atau interaksi antara suami dan istri atau ayah dan ibu sangat menentukan kesuksesan pendidikan karakter di lingkungan keluarga untuk menciptakan suasana edukatif dan interaksi edukatif. Situasi edukatif adalah terciptanya suasana yang memungkinkan terjadinya proses pendidikan. Sementara interaksi edukatif adalah interaksi yang mengandung nilai pendidikan. Situasi dan interaksi edukatif harus diciptakan oleh suami istri atau ayah ibu, dan orang-orang dewasa lain yang bertanggungjawab dalam pelaksanaan pendidikan karakter di lingkungan keluarga.

b. Model interaksi antara orang tua dan anak

Hal yang perlu diperhatikan orang tua dalam membangun hubungan atau interaksi yang baik dengan anaknya sebagai berikut:

1) Memposisikan dirinya sebagai orang yang punya otoritas tinggi

Pada masa golden age, orang tua harus memiliki kemampuan otoritas yang tinggi dalam pembentukan karater anak. Sehingga apapun yang dikatakan orang tua, anak menerima kebenaran itu tanpa reserve. Pada masa ini anak tidak bisa diberikan banyak pilihan sebab perkembangan otak anak pada saat ini yang menonjol adalah verbalistik, yaitu kemampuan ingatan/hafalan. Disinilah peran orang tua sangat besar sekali, sehingga bisa dikatakan orang tua adalah pendidik yang pertama dan utama.

2) Menyediakan waktu untuk anak.

Pada masa usia dini, secara psikologis anak membutuhkan perhatian dan kasih sayang secara mutlak dari orang tua. Untuk itu orang tua harus banyak meluangkan waktu kepada anak agar proses pendidikan karakter yang diharapkan bisa mudah tercapai.

3) Mampu mengenali bahasa tubuh anak

Pada saat tertentu, anak usia dini tidak bisa mengungkapkan sesuatu untuk memenuhi keinginannya, tidak bisa berkata-kata, tidak bisa ber statement, dari sinilah maka anak tersebut banyak bertingkah. Hal itu dilakukan sebagai bentuk ekspresi tubuhnya yang mempunyai maksud untuk meminta sesuatu. 


\section{Rizqiyah Ratu Bilqis}

\section{Pola Asuh Anak}

Dalam perkembangan ada 2 unsur yang harus dipenuhi. Yakni perkembangan jasmani dan perkembangan rohani. Perkembangan jasmani anak, sangat bergantung pada gizi yang terdapat dalam makanan. Jika asupan makanan yang diberikan telah sesuai dengan kebutuhan gizi anak, maka perkembangan dan pertumbuhan jasmani akan berjalan dengan baik. Sedangkan perkembangan rohani (jiwa) anak bergantung pada pola pendidikan yang harus disesuaikan pada masa/fase perkembangan jiwa anak. Pada masa anak usia dini, yang perlu diperhatikan dalam memberikan pendidikan karakter adalah dengan pola asuh yang berorientasi pada kenyamaan jiwa anak. Sehingga bentuk pendidikan yang berupa punishment pun harus bisa menyenangkan jiwa anak.

\section{PENUTUP}

Konsep nilai pendidikan karakter yang dapat diambil dalam QS Luqman ayat 12-19 adalah karakter religius yang diantaranya adalah; 1) Pendidikan ke-tauhida-an yakni mengakui ke-Esa-an Allah SWT, dan segala sesuatu didunia ini Allah lah yang menentukan, 2) birrul walidain, yakni pendidikan kepatuhan anak terhadap orang tua, 3) pendidikan bersyukur, yakni menerima dan memelihara segala nikmat yang telah diterima, 4) pendidikan kesabaran, yakni memiliki keteguhan dan ketahanan mental dalam setiap apa yang dilakukan, 5) pendidikan ibadah, yakni senantiasa menjalan ibadah secara sempurna sebagai bentuk aplikasi sebuah keimanan, 6) amar ma`ruf nahi mungkar, yakni berani dan siap menerima kebenaran dan menolak kemungkaran, 7) pendidikan karakter jujur, yakni segala sesuatu harus dilandasi dengan rasa kejujuran sehingga hidup menjadi lebih aman tentram bahagia baik didunia maupun diakhirat.

Model pendidikan karakter untuk anak usia dini yang terdapat dalam QS Luqman ayat 12-19 adalah :

1. Model Interaksi dalam keluarga, yang di dalamnya terdapat model interaksi antar orang tua yakni interaksi ayah dan ibu, dan model interaksi antar orang tua dan anak.

2. Model Pola Asuh, yakni yang mengutamakan dan menekankan pertumbuhan serta perkembangan anak pada jasmani dan rohaninya.

\section{DAFTAR PUSTAKA}

Vol. I. No. Q2. Dktober 20I9

Jurnal Auladuna | 6 | 
Abdullah bin Muhammad bin Abdurrahman Alu Syaikh. 2008. Tafsir Ibnu Katsir,Juz,21, (Jakarta: Pustaka Imam Asy-Syafi'I)

Al-Ghamidi, Abdullah.2011. Cara MengajarAnak/Murid ala Luqman al-Hakim. Yogyakarta: Sabil.

Al-Maraghi, Ahmad Mustafa. 1992. Tafsir Al-Maraghi, Juz XXI, (Semarang: Toha Putra).

Al-Qurthubi, Syaikh Imam. 2009. Tafsir Al-Qurthubi, (Jakarta: Pustaka Azzam)

Anwar, Abu. 2009. Ulumul Qur'an, (Jakarta: Amzah)

Damayanti, Deni. Panduan Implementasi Pendidikan Karakter di Sekolah. Yogyakarta : Araska, 2014.

Departemen Agama RI, Al-Qur'an dan Tafsimya, Jil VII

Istadi, Irawati. 2017. Rumabku Tempat Belajarku. Yogyakarta : Pro-U Media

Kementerian Pendidikan Nasional. 2010. Pengembangan Pendidikan budaya dan Karakter Bangsa, (Jakarta: Badan Penelitian dan Pengembangan Pusat Kurikulum)

Muhammad Hasbi ash-Shiddiqi. 2000. Tafsir Al-Qur'anul Majid An-Nuur, (Semarang: Pustaka Rizki Putra)

Muslich, Masnur. (2011). Pendidikan Karakter: Menjawab Tantangan Krisis Multidimensional. Jakarta: PT Bumi Aksara.

Shihab, Quraish. 2012. Al-Lubab, (Jakarta: Lentera Hati)

Suma, Muhammad Amin. 2013. Ulumul Qur'an, (Jakarta: RajaGrafindo Persada)

Jurnal Auladuna | 62 